Кривошапко Сергей Николаевич (Москва). Доктор технических наук, профессор. Профессор-консультант Инженерной академии ФГАОУ В0 «Российский университет дружбы народов» (117198, Москва, ул. Миклухо-Маклая, 6. РУДН). Эл. почта: sn_krivoshapko@mail.ru

Алборова Лана Анатольевна (Москва). Бакалавр строительства и технологии. Магистрант по направлению подготовки «Архитектура» Инженерной академии ФГАОУ В0 «Российский университет дружбы народов» (117198, Москва, ул. Миклухо-Маклая, 6. РУДН).

Мамиева Ираида Ахсарбеговна (Москва). Ведущий специалист Инженерной академии ФГАОУ В0 «Российский университет дружбы народов» (117198, Москва, ул. Миклухо-Маклая, 6. РудН). Эл. почта: i_mamieva@mail.ru.

Krivoshapko Sergey N. (Moscow). DSc, Professor. Professor-tutor at the Engineering Academy of the Peoples' Friendship University of Russia (6 Miklukho-Maklaya St., Moscow, 117198. RUDN University). E-mail: sn_krivoshapko@mail.ru

Alborova Lana A. (Moscow). Bachelor of Construction and Technology. The magistrates "Architecture”. The Engineering Academy of the Peoples' Friendship University of Russia (6 Miklukho-Maklaya St, Moscow, 117198. RUDN University).

Mamieva Iraida A. (Moscow). Lead Specialist at the Engineering Academy of the Peoples' Friendship University of Russia (6 Miklukho-Maklaya St. Moscow, 117198. RUDN University).E-mail: i_mamieva@mail.ru.

(๑) Кривошапко С.Н., Алборова Л.А., Мамиева И.А., 2021. Academia. Архитектура и строительство, № 4, стр. 110-119.

\title{
Оболочечные структуры: генезис, материалы и подвиды. Часть 2. Кон- струкционные строительные материалы *)
}

С.Н.Кривошапко, РУДН, Москва

Л.А.Алборова, РУДН, Москва

И.А.Мамиева, РУДН, Москва

\section{Введение}

В статье [1] рассмотрены практически все архитектурные стили, стилевые течения и направления, в рамках которых проектируются тонкостенные оболочки и оболочечные структуры. Некоторые объекты могут быть отнесены сразу к нескольким стилям или в одном объекте могут быть найдены элементы разных стилей. Все архитектурные стили и направления применительно к оболочкам, оболочечным и многогранным структурам, их основатели, годы возникновения и затухания стилей отражены в таблице в ранее опубликованной статье авторов [1].

Целью данного исследования является анализ информации о конструкционных материалах и примерах воплощения архитектурных стилей в реальные оболочки и оболочечные структуры из разнообразных строительных материалов. Одна из первых попыток решить эту задачу была предпринята С. Красик [2].

*) «Часть 1. Подвиды и направления» статьи «Оболочечные структуры: генезис, материалы и подвиды» опубликована в № 3 журнала «Academia. Архитектура и строительство» за этот год.

\section{Хронология появления конструкционных строитель- ных материалов}

Конструкционные строительные материалы включают в себя множество различных материалов, применяемых для изготовления оболочечных структур. В распоряжении конструктора имеется широкий спектр материалов и конструкций из них: каменные материалы, кирпичи из обожженной глины, древесина, клеёная древесина, металлы, железобетон, пластмассы, композиционный материал, стеклопластики, стекло, тентовые ткани и др. В разные исторические эпо-хи архитекторы и инженеры отдавали предпочтение тому или иному конструкционному материалу.

Камень - один из древнейших, используемый человеком строительный материал. В основном для строительства куполов и сводов использовался известняк, мрамор, тесаный камень.

Самые древние кирпичи из обожжённой глины возрастом около 7000 лет были найдены на территории южной Турции на месте древнего поселения недалеко от города Иерихона. В Россию кирпич завезли византийские мастера, которые прибыли в страну после крещения Руси в $X$ веке. 
Первым кирпичным строением стала Десятинная церковь в Киеве (988-996). До конца XIX века кирпичи изготавливали вручную.

Древесина является химически более стойким материалом, чем металл и железобетон. Деревянные конструкции в условиях постоянного или периодического длительного нагрева допускается использовать, если температура окружающего воздуха не превышает $50^{\circ} \mathrm{C}$.

В России клеёная древесина широко применялась и была незаслуженно забыта в угоду железобетону в 60-е годы прошлого века. С середины 90-х годов забытая ранее технология начала возрождаться в частном секторе индивидуального домостроения, а затем и для строительства сооружений с большими пролётами.

Металлы подразделяются на чёрные и благородные. Иногда говорят о лёгких и тяжёлых металлах. В строительстве в качестве конструкционных материалов применяют сталь, чугун и алюминий.

Стальные тросы с 1870 года изготавливаются из пучков высокопрочной проволоки. В. Альберт в 1827 году предложил делать тросы путем свивания проволоки. Первая машина для изготовления тросов появилась в 1840 году.

Титан известен более двухсот лет и с тех пор не теряет своей популярности. В строительстве используется его стойкость к механическому воздействию, к коррозии и химическим веществам. В восточных странах титан используют в качестве кровельного материала. Им часто облицовывают здания.

Железобетон как новый материал был запатентован садовником из Версаля Ж. Монье (J. Monier). Он получил патент в 1867 году на цементную кадку для пальм, армированную железной сеткой. Именно этот год и считается официально годом рождения железобетона.

Армоцементные конструкции - это тонкостенные железобетонные конструкции толщиной не более 30 мм из мелкозернистого бетона с арматурой из частых тканых или сварных сеток из тонкой стальной проволоки или композитных материалов. Армоцементные конструкции используют для пространственных покрытий в виде оболочек и складок. Впервые армоцемент был использован во второй половине XIX века. В середине XX века П.Л. Нерви построил первые сооружения с использованием армоцемента.

Пластмассы - большая группа искусственных материалов, полученных на основе синтетических или природных высокомолекулярных соединений (смол). В начале XX века возникло промышленное производство синтетических соединений. Начиная с 30-х годов, количество вырабатываемых смол и пластмасс достигло промышленных масштабов и их стали применять в промышленности, а затем и в строительстве.

Композиционный материал - искусственно созданный неоднородный сплошной материал, состоящий из двух или более компонентов с чёткой границей раздела между ними. Наполнители вводятся с целью повышения физико-механических свойств материала.
Строительное силикатное стекло иногда включают в конструкции, где оно выполняет не только свою функцию светопрозрачного ограждения, но и является конструкционным строительным материалом. В настоящее время не существует международных признанных норм по проектированию стеклянных элементов конструкций, таких как известные европейские стандарты - Еврокоды (Eurocode) - для других строительных материалов.

Стеклопластики - это пластмассы, состоящие из стекловолокнистого наполнителя и полимерного связующего.

Ткани, предназначенные для тентовых покрытий, должны отвечать основным требованиям, предъявляемым к таким конструкциям: трудновоспламеняемость, работоспособность при низких температурах, биостойкость, большие гарантийные сроки эксплуатации. В 1920-х годах роль тентов для покрытий выполнял прорезиненный брезент.

Хронология появления основных конструкционных строительных материалов показана в таблице 1.

\section{Пространственные большепролётные сооружения и тонкостенные оболочки}

История строительства каменных куполов насчитывает 2000 лет. Самый древний каменный купол у храма-ротонды Пантеона в Риме (около 125 года), диаметр купола - 43,2 м. Широко известен купол из белого мрамора мавзолея Тадж-Махал (1632-1653. Агра, Индия). Меньше известны трулли - традиционные каменные жилища в городах Апулии (Италия) с коническими крышами из блоков известняка.

Самый большой кирпичный купол у собора Санта-Мария дель Фьоре. Строительство здания началось во Флоренции ещё в 1296 году. Даже в наше время в некоторых странах Латинской Америки и Африки строят кирпичные купола из обожженной глины (рис. 1).

Железобетонные оболочки в форме параболического цилиндра арочного типа пролётом 30 м, построенные в 1905 году французским инженером Е. Фрейсине (E. Freyssinet), считаются первыми пространственными железобетонными структурами оболочечного типа. В России в 1909 году впервые была по-строена железобетонная винтовая лестница в форме прямого геликоида [3], а с 1929 года началось широкое применение железобетона при строительстве индустриальных зданий. В 1960 году в СССР в Тбилиси был построен первый купол из сборного железобетона. С тех пор не прекращались работы по совершенствованию конструктивно-технологических возможностей сборных оболочек [4]. После 1965 года наступил 30-летний перерыв, во время которого возводились только технологические оболочки, например, градирни. В 1995-ом начался медленный рост интереса к проектированию железобетонных оболочек. В начале XXI века железобетонные и армоцементные тонкостенные оболочки используются больше в малогабаритном строительстве, то есть для строительства кафе, небольших офисов, навесов и т.п. Для возведения по- 
крытий промышленных сооружений или в сооружениях, где этого требуют технологические процессы, железобетонные оболочки больших пролётов практически не возводились.

В 1950 году архитекторы М. Лоретта и М. Марги в городе Чианчиани (Италия) построили зал для танцев с куполом в форме эллипсоида вращения диаметром 21 м. При строительстве использовалась опалубка из сборных армоцементных сегментов. Другое направление применения армоцемента в архитектуре большепролётных сооружений, реализованное П.Л. Нерви, - использование тонкостенных сборных элементов в качестве несущих конструкций. В 1948-1949 годы при строительстве выставочного павильона в Турине П.Л. Нерви впервые применил в качестве несущей конструкции тонкостенный армоцементный свод пролетом 72 м, образованный из однотипных сборных элементов складчатого поперечного сечения шириной 2,5 м, высотой 1,45 м. Элементы объединялись сваркой арматуры и последующим замоноличиванием стыков.

Деревянные структуры. История строительства деревянных оболочек насчитывает несколько столетий. Она начиналась с шатровых покрытий сооружений башенного типа и куполов церквей. Принципиально новые конструкции большепролётных деревянных оболочек появились в 1920 е годы (рис. 2). В послевоенные годы в СССР вследствие широкого развития заводского производства сборного железобетона и металлических конструкций, обеспечивавших в тот период наиболее быстрое решение градостроительных задач и задач по восстановлению и дальнейшему развитию индустрии, строительство зданий и сооружений из дерева в крупных городах значительно сократилось. Применение деревянных оболочек значительно расширилось, когда в 1960-е годы появились клеевые деревянные конструкции. Особенно эффективно применение клеёной древесины в большепролётных арочных, купольных и сводчатых покрытиях зданий и сооружений (рис. 3). Тонкостенные своды из клеефанерных полотнищ имеют стрельчатое или круглое очертание с затяжкой или с передачей распора непосредственно опорам [5]. Купольные покрытия из арочных клеёных деревянных рёбер и сетчатые деревянные своды используются для общественных зрелищных и спортивных

Таблица 1. Конструкционные материалы для строительных конструкций

\section{Конструкционные материалы для строительных конструкций}

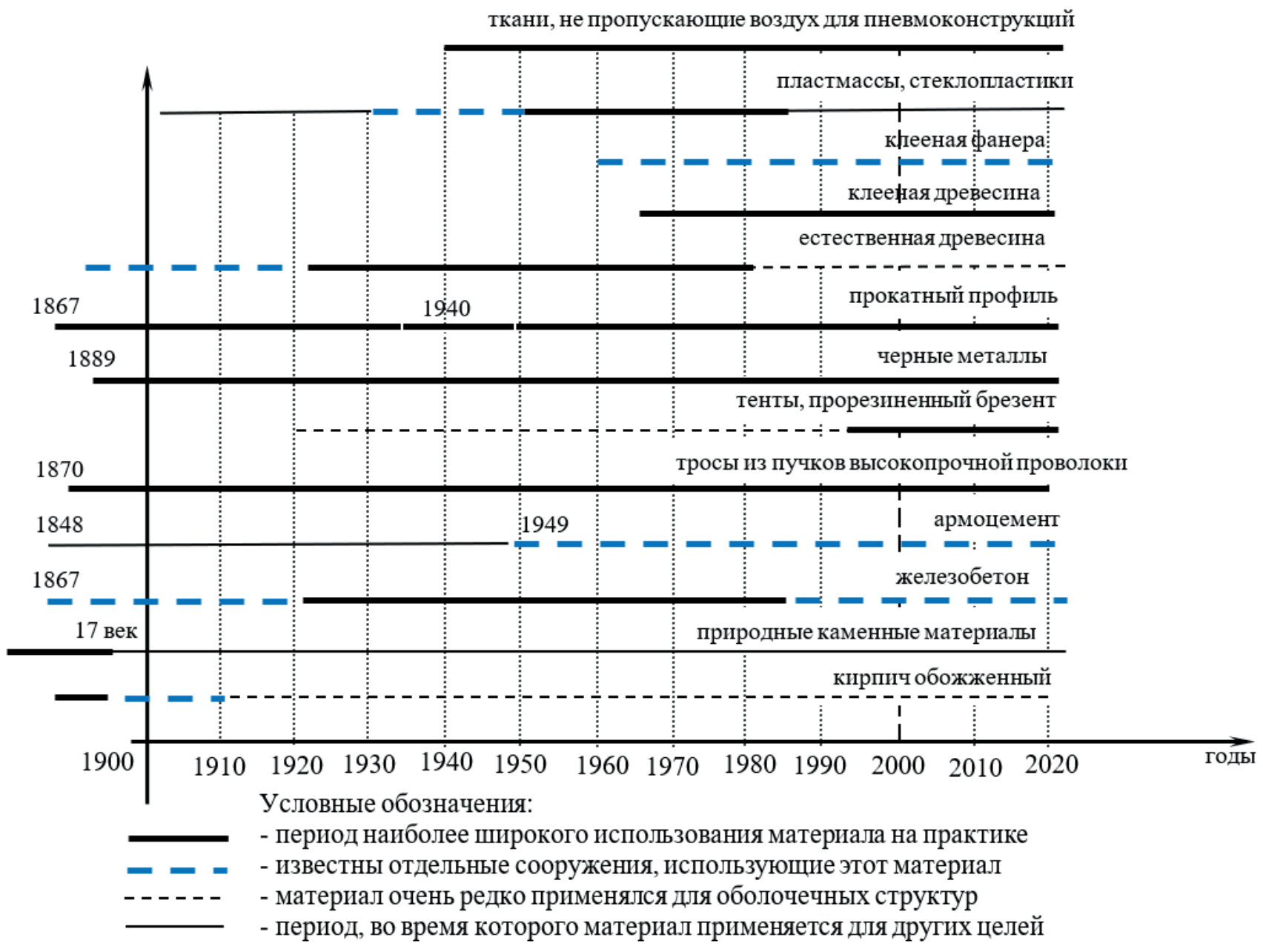


сооружений. Находят применение оболочки других форм: гипары, оболочки сложных, составных форм и произвольной формы, не поддающиеся математическому описанию.

Пластмассовые оболочки. Вначале пластмассы использовали в качестве теплоизоляции (пенопласт, сотопласт и др.), затем они нашли применение в пневматических конструкциях (прорезиненная ткань, армированная пленка). Во время Второй мировой войны появились первые пластмассовые сооружения для военных целей. В 50-е годы XX века для изготовления малопролётных куполов стали использовать листовой пластик (Б. Фуллер, 1950-е годы, США). В СССР тоже изготавливались малопролётные купола из синтетических ма-

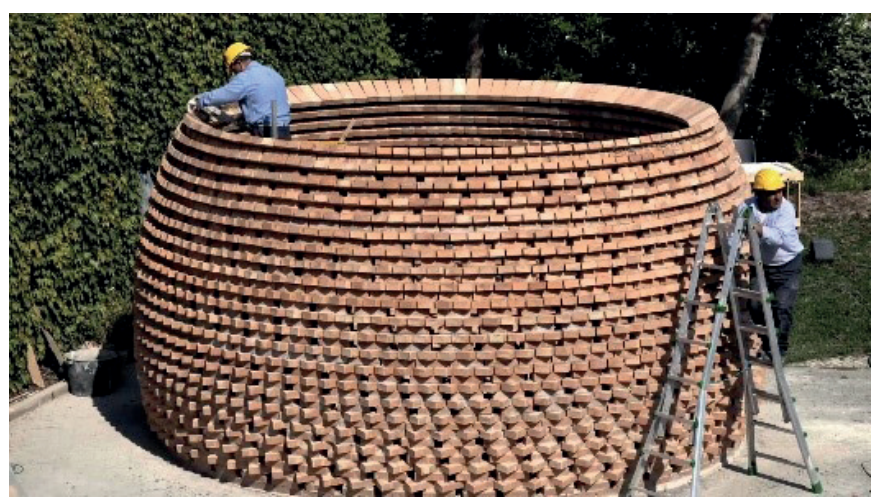

Pис. 1. Строительство купола из кирпичей из обожжённой глины ${ }^{1}$

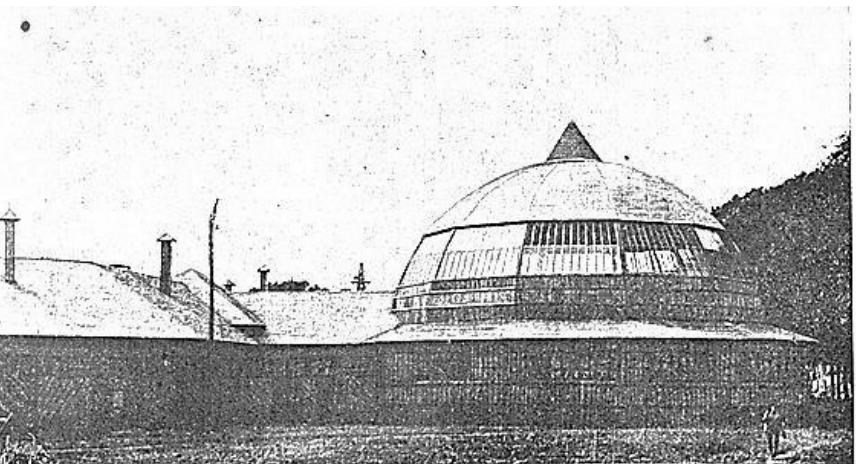

Pис. 2. Первый деревянный купол в России. Манеж животноводства на ВСХВ. Москва. 1923 год

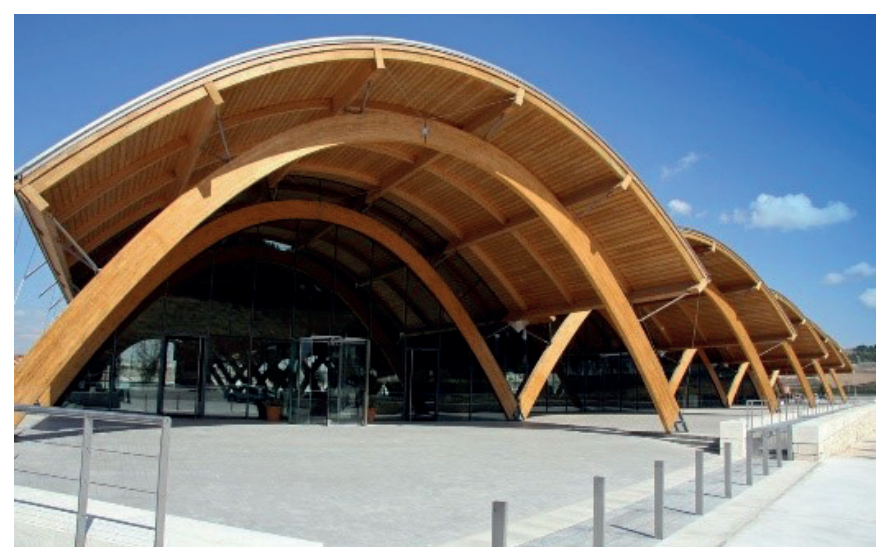

Pис. 3. Свод из клеёной древесины териалов. Для примера можно привести экспериментальный жилой дом для Заполярья, запроектированный инженером Бодянским из сборноразборных элементов. НПО «BASKEY» (Новосибирск) осуществляет проектирование и строительство купольных домов из пенопласта. Стандартный дом - это купол диаметром 8 м с высотой стенок 4 м, толщиной стенок 8-19 см (рис. 4). 0бшивка из полиэфирного стеклопластика толщиной 2,5 мм, средний слой из пенополиуретана толщиной 4 см применены в оболочке типа «Futuro» для горной гостиницы в Домбае и для аналогичной формы кафе в Краснодаре (рис. 5). В настоящее время считается, что самый большой в мире композитный купол - это купол мечети в Бахрейне диаметром 25 м.

Пневматические оболочки разделяются на воздухоопорные (воздухонадувные) оболочки и воздухонесомые покрытия. Пневматические конструкции изобретены в 40-х годах XX века [6]. Первая строительная пневматическая конструкция с размерами в плане $60 \times 20$ м и высотой 6 м для проектного бюро появилась в 1946 году в городе ХемелХемпстед (Англия). В США впервые применили однослойное пневматическое покрытие из стекловолокнистой ткани толщиной 2,4 мм, подкреплённое 12-ью стальными тросами диаметром 48 мм, для павильона США на выставке ЭКСП0-70 в 0саке [7]. Развитие пневматических конструкций в СССР проходило в три этапа: начальный период (1959-1970); период подготовки выпуска серийных воздухоопорных пневматических сооружений (1970-1975) и период их серийного выпуска после 1975 года (рис. 6) [6].

${ }^{1}$ Все иллюстрации, использованные в статье, кроме особо оговоренных, взяты из открытых источников сети Интернет.

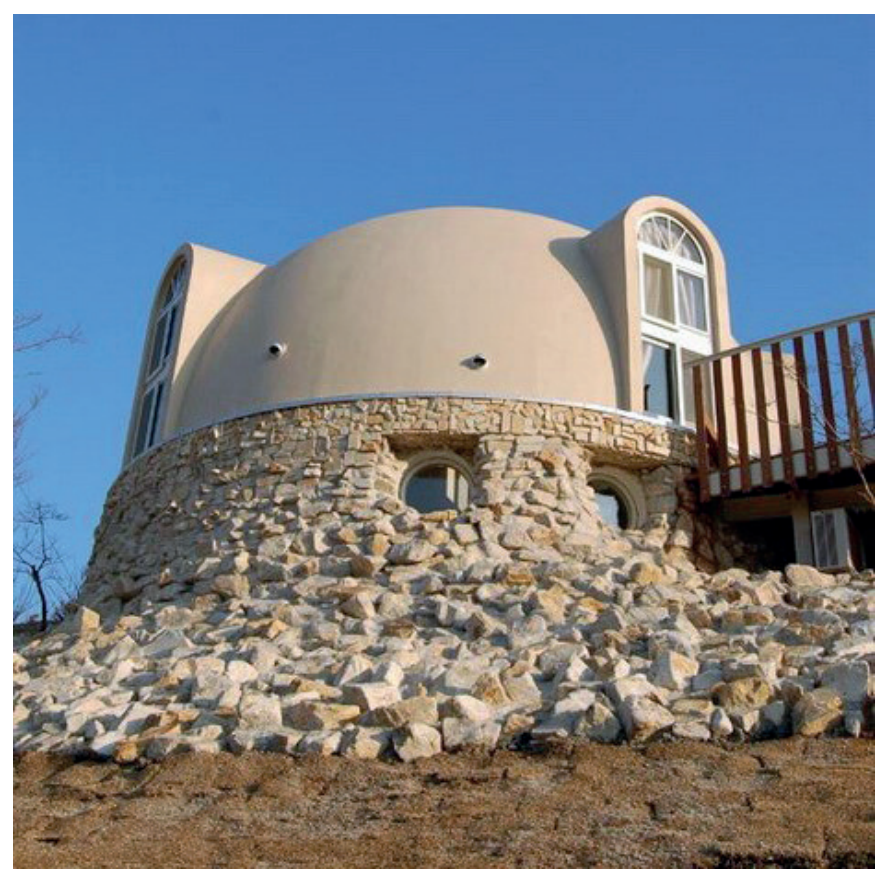

PUс. 4. Купольный дом из пенопласта объединения «BASKEY» 
Хотя примитивные тентовые сооружения появились ещё в глубокой древности, тентовые покрытия получили признание как явление архитектуры высоких технологий только после 1983 года, хотя ещё в 1950-1960-е годы немецкий архитектор Ф. Отто перешёл от экспериментов с моделями к полноразмерным сооружениям. В 1930-1970 годы развитие тентовых покрытий в нашей стране находилось всё ещё в начальной стадии. После победы датского архитектора Й.0. Спрекельсена (Johan Otto von Spreckelsen) в конкурсе на Арку Дефанс в Париже (1983) тентовые покрытия получили признание как явление архитектуры. К заметным сооружениям мирового значения можно отнести купол Центра «Sony» на Потсдамер-плац в Берлине, открытый в 2000 году. Главным архитектором центра был Гельмут Ян (Helmut Jahn). Начало XXI века, времени расцвета строительства тентовых сооружений, известно не только грандиозными тентовыми сооружениями [8], но и массовым внедрением небольших временных тентовых сооружений для разнообразных нужд человека.

В вантовых системах ванты или тросовые плоские, или пространственные фермы поддерживают в проектном положении жёсткие элементы (балки, плиты, арки, рамы), работающие на изгиб, а уже на эти жёсткие элементы укладывают ограждающие конструкции (рис. 7). В 1929 году было возведено вантовое покрытие летней эстрады ЦПКи0 в Москве по проекту Г.М. Людвига в стиле символико-инженерного функционализма [1]. Первое подвесное наклонное покрытие автобусной остановки с кровлей из прозрачной пластмассы было подвешено к наклонным несущим стойкам системой вант в 1949 году в Милане (Италия). Вантовые конструкции признаются инновационными конструктивными решениями [9], выполненными в архитектурном стиле хай-тек.

Висячие тросовые конструкции отличаются от вантовых систем тем, что ограждающие элементы в них укладывают-



Pис. 5. Кафе. Краснодар. Фото С.Н. Кривошапко

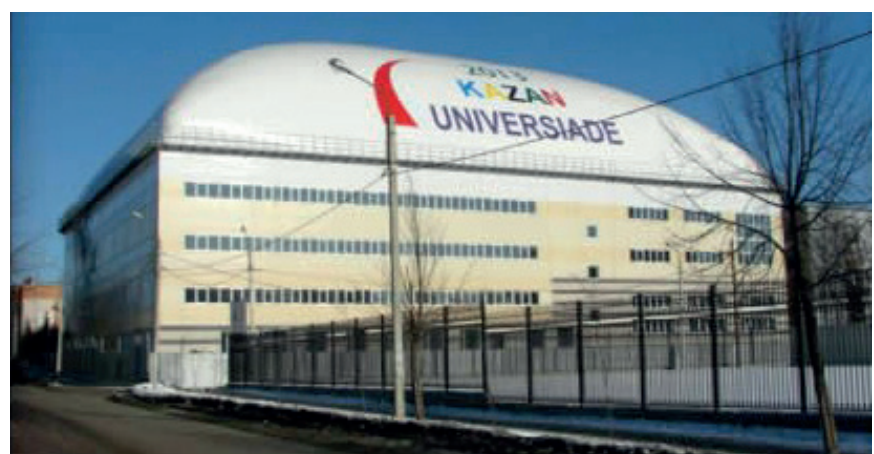

Рис. 6. Воздухоопорное сооружение на крыше спорткомплекса. Казань. Дата установки - февраль 2009 года

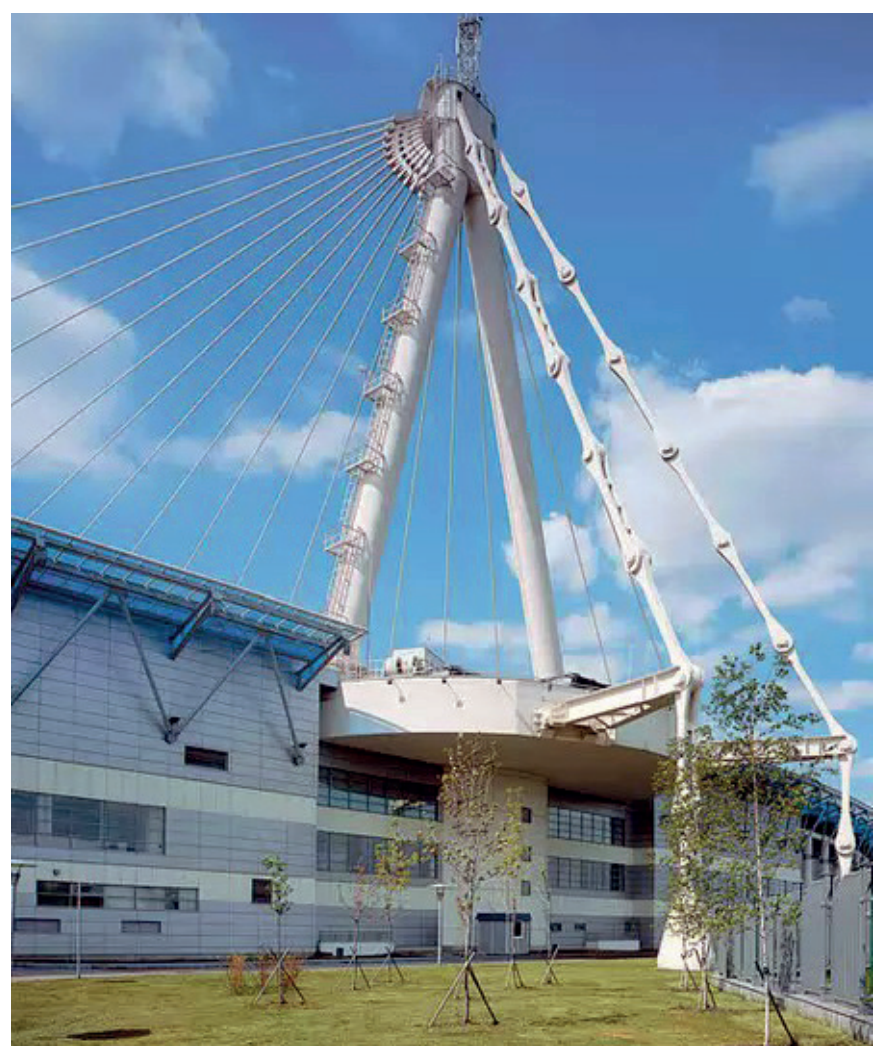

Рис. 7. Вид на Ледовый дворец в Крылатском со стороны единственного пилона. Москва

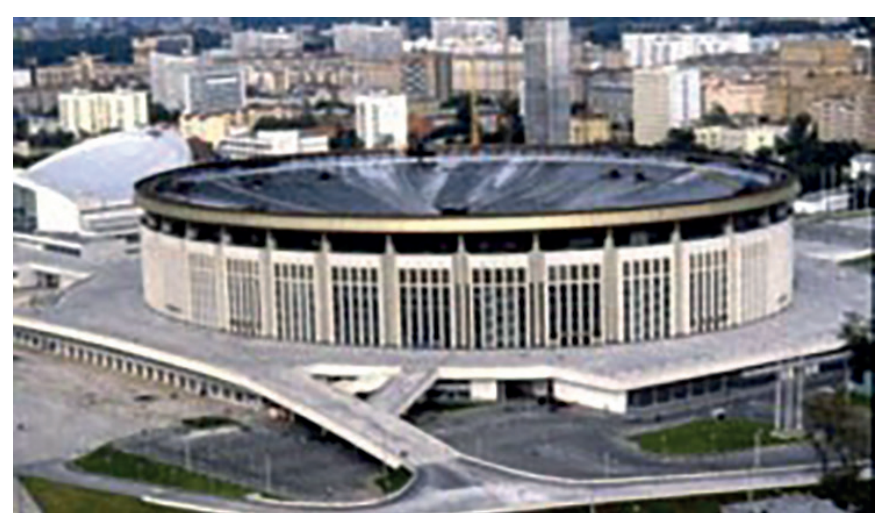

Puс. 8. Самое большое стальное мембранное висячее покрытие в мире над спорткомплексом на проспекте Мира в Москве. Было разобрано в 2019 году по плану реконструкции комплекса 
ся непосредственно на тросы или тросовую сеть. Первые висячие конструкции тросового типа из узких железных полос были сооружены В.Г. Шуховым в 1896 году на Нижегородской ярмарке. Одним из первых тросовых сооружений за рубежом стала крытая хоккейная площадка, запроектированная Е. Саариненом (E. Saarinen) и построенная в 1958 году. Покрытия из тросовых сеток обладают очень широкими возможностями формообразования, которые ограничены лишь несущей способностью нитей и опорного контура. До 1977 года только в СССР было построено свыше 120 зданий, перекрытых висячими конструкциями. B XXI веке, по мнению П.Г. Еремеева [10], ещё больше возрастает интерес к проектированию и строительству большепролётных сооружений, в том числе висячих тросовых конструкций. Практически все построенные сооружения этого типа можно назвать уникальными и выдающимися.

Металлические мембранные висячие покрытия применяются значительно реже, чем другие виды висячих покрытий. Металлические мембранные висячие покрытия, или просто - мембранные покрытия, представляют собой пространственную конструкцию, состоящую из тонкого металлического листа и жёсткого опорного контура. За рубежом листовое покрытие элеватора в США появилось впервые только через 35 лет после первых мембранных покрытий из стальных лент и кровельной стали, разработанных В.Г. Шуховым (1896) для четырёх павильонов на Всероссийской художественной и промышленной выставке в Нижнем Новгороде. Но 0. Фрей в своей книге «Подвесные крыши» утверждает, что эпоха подвесных покрытий из листовой стали началась в 1937 году с выставочного павильона в Загребе ${ }^{3}$. В Северной Америке возведение растянутых мембран началось в 1970 году. В нашей стране накоплен значительный опыт по расчёту, проектированию и строительству различных типов мембранных покрытий, позволивший возвести ряд уникальных большепролётных покрытий для спортивных сооружений Олимпиады-80 (рис. 8), но за проектирование и сопровождение строительства мембранных висячих оболочек и ленточных покрытий в наше время берутся немногие конструкторские бюро и проектные организации, хотя теоретически решены все вопросы [11].

Стальные стержневые структуры прочно занимают свою нишу в архитектуре общественных и промышленных зданий (рис. 9). Первые оболочечные конструкции с применением металла - купола, своды, навесы - появились в средние века. Покрытие крыльца Невьянской башни на Урале (1725) считается первой чугунной конструкций в России. Однако стержневые пространственные конструкции стали сооружаться в самом конце XIX века. Это связано со сложностью устройства узловых соединений и отсутствием потребностей в возведении этих структур. Первая стержневая пространственная мачтовая структура была возведена Г. Эйфелем для Всемирной выставки 1889 года в Париже. В

${ }_{3}^{3}$ Фрей 0. Подвесные крыши [Das Hängende Dach]. - Берлин, 1954.

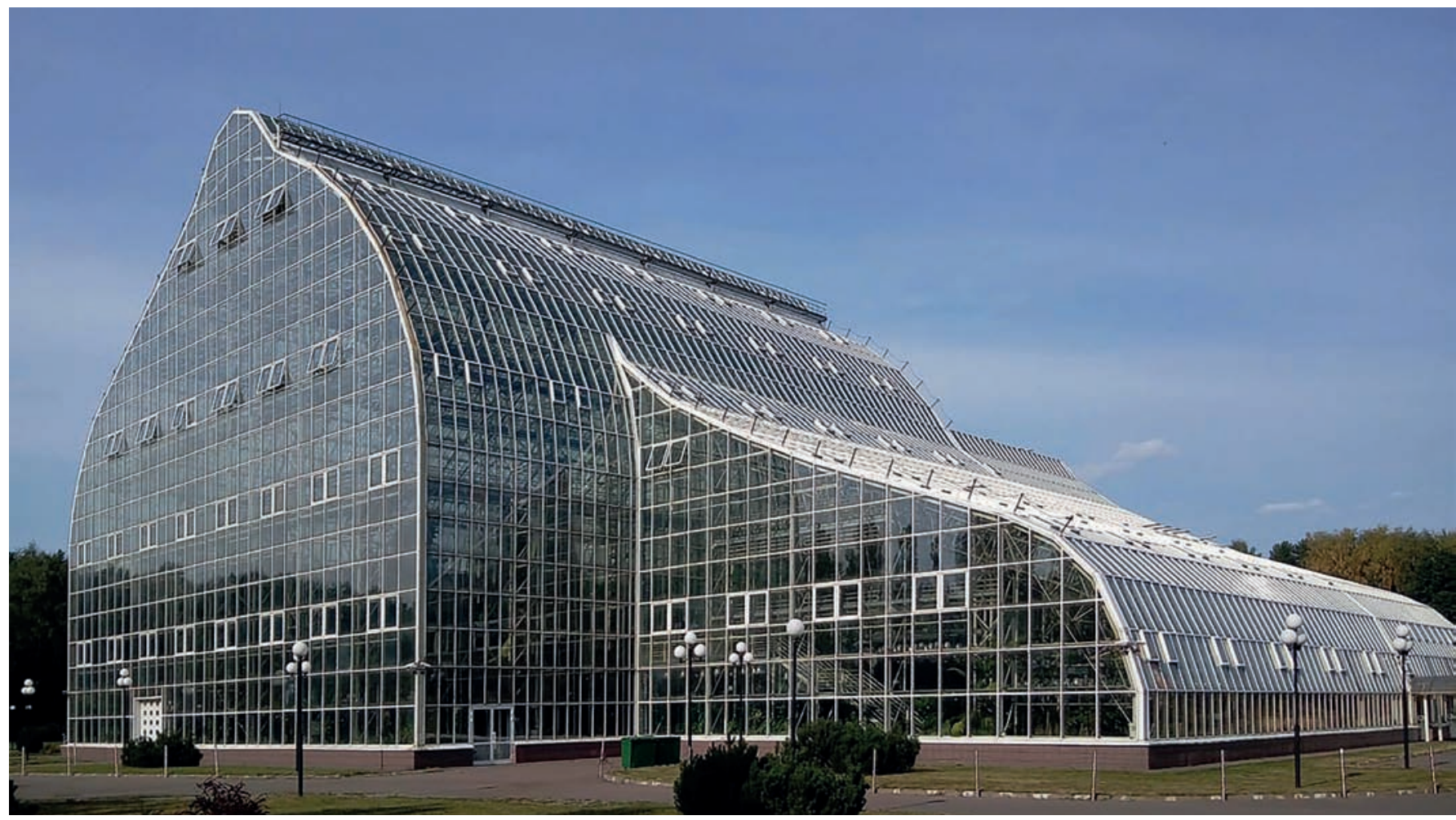

Рис. 9. Фондовая оранжерея Главного ботанического сада им. Н.В. Цицина РАН. Москва 
самом конце XIX века В.Г. Шухов построил первую в мире решётчатую гиперболическую башню, а затем оболочку двойной кривизны. В России его считают родоначальником стержневых металлических конструкций. К наиболее ярким металлическим оболочкам, возведённым в XXI веке, можно отнести комплекс Большого народного театра (China National Grand Theatre, 2007) из титана и стекла, ставший символом Китая. Комплекс спроектировал известный французский архитектор Поль Андрё (Paul Andreu). Новые формы для стержневых однослойных структур предлагаются в [12]. Сейчас в основном строят металлические стержневые оболочечные трёхмерные структуры. Толщины оболочек стали достигать нескольких метров при очень больших пролётах. Оболочки стали трёхслойными: наружный и внутренний слои выполняются из листового металла, а внутренний слой представляет собой стержневую структуру.

Цельнометаллические оболочки с элементами усиления применяются, в основном, в качестве резервуаров для хранения нефти [13], воды и газов (газгольдеры).

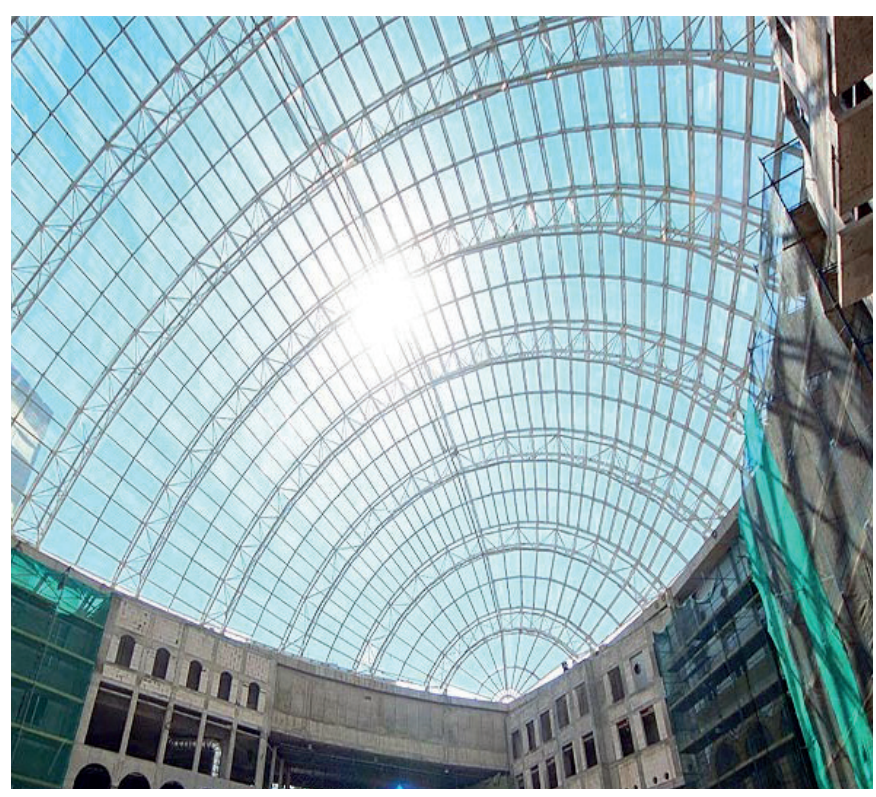

Рис. 10. Стеклянный купол в Нагатинской пойме Москвы

Таблица 2. Пространственные сооружения и оболочки

\section{Пространственные сооружения и оболочки}

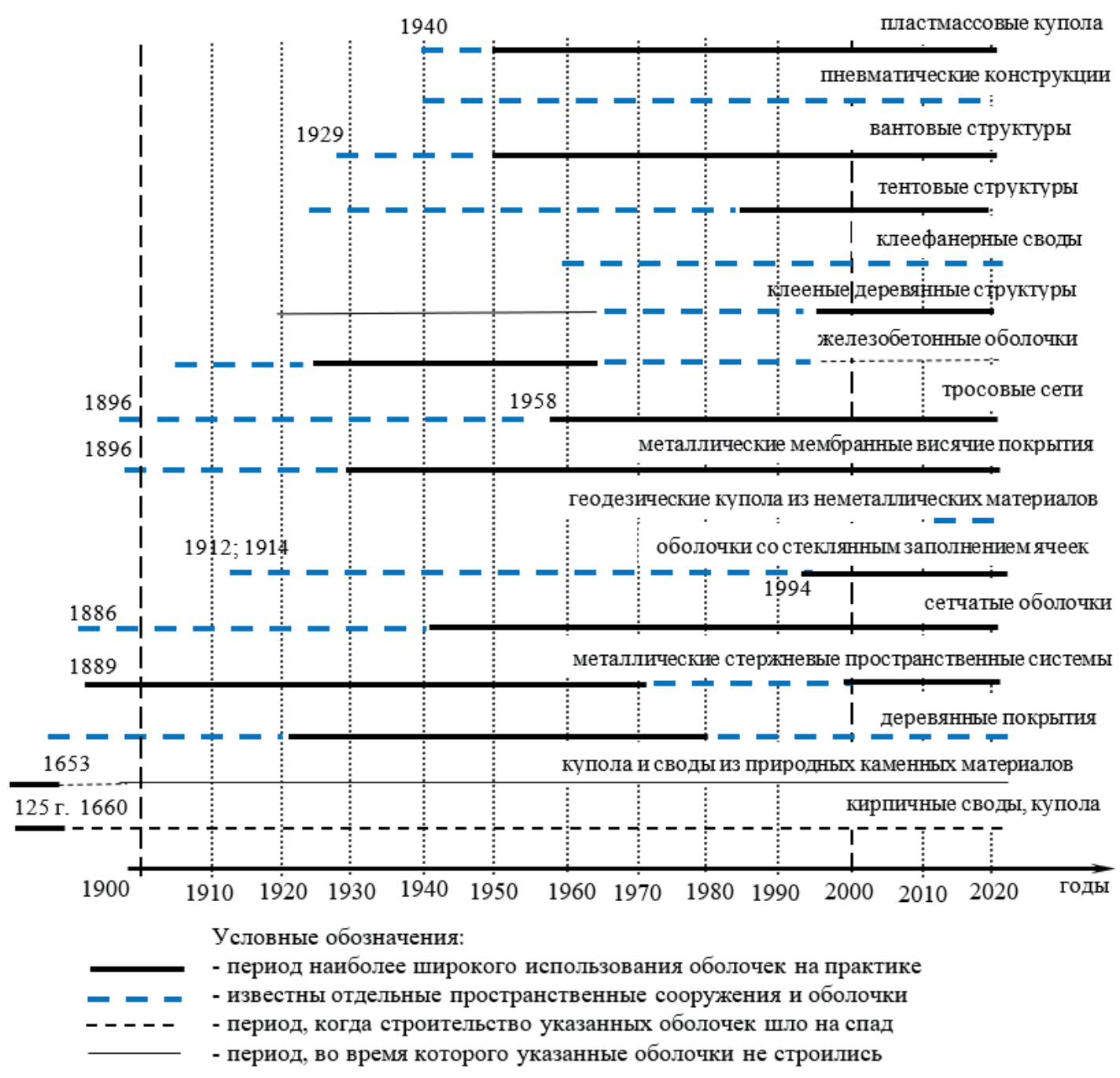


Стальные сетчатые оболочки. В строительной практике железобетонные несущие оболочки, несколько аварий которых произошли в России в последние годы, постепенно вытесняются сетчатыми несущими оболочками. Стальные сетчатые оболочки зданий и сооружений эксплуатируются в российском климате безаварийно, а сетчатые оболочки В.Г. Шухова не разрушаются без защиты от коррозии 70-100 лет. В последние годы сетчатые оболочечные структуры применяют чаще, чем железобетонные тонкостенные оболочки. Геодезические купола, и не только металлические, - наиболее яркие представители сетчатых оболочек, к которым применим архитектурный стиль геометрический хай-тек [14].

Tитан применялся в виде титановых панелей для покрытия Большого Народного театра, Китай (2007) и для эллиптической конструкции двухсотметровой длины из титана над залом для пассажиров транспортного узла в Сингапуре на 17000 пассажиров в часы пик (2001).

Деревянные и полимерные геодезические купола в некоторых случаях имеют определённые преимущества перед металлическими геодезическими куполами. В этом уверены авторы [14] из СПбГАСУ. Их теоретические и экспериментальные исследования подтверждают это. Они утверждают, что 2017 год можно считать годом начала активного строительства деревянных и полимерных геодезических куполов.

Стекло обычно используется для изготовления тонкостенных оболочек малых размеров, например, для светопрозрачных фонарей общественных и промышленных зданий. Если стекло не является несущим элементом, то стеклянные оболочки могут достигать внушительных размеров. Первые своды и купола со стеклянным заполнением появились почти одновременно с началом строительства металлических стержневых пространственных систем. Вероятно, 1912 год - год окончания строительства стеклянного покрытия Московского главпочтамта по проекту Шухова - можно считать годом начала эпохи стеклянных сводов и куполов. Или принять за точку отсчета можно 1914 год - год окончания строительства «Стеклянного дома» [архитектор Б. Таут (Bruno Taut), Кёльн]. Началом очередного этапа можно считать 1994 год, когда Н. Фостеру была присуждена международная премия за стеклянный купол над Рейхстагом в Берлине. В Нагатинской пойме Москвы-реки смонтирован самый большой в России стеклянный купол (рис. 10). Его площадь составляет 8000 кв. м - это в семь раз больше, чем купол над галереей Виктора Эммануила в Милане и в 2,5 раза чем купол Н. Фостера над Рейхстагом. Высота купола, который расположился над центральным атриумом развлекательного центра «0строва мечты», составляет 35 метров.

Известны бескаркасные стеклянные купола Л. Бландини (Lucio Blandini) из Университета в Штутгарте ${ }^{4}$ [15].

Хронология появления пространственных большепролётных сооружений и тонкостенных оболочек с соответ- ствующими датами их возведения, с кратким описанием их конструкций приведена в таблице 2.

Существует много классификаций тонкостенных пространственных форм и оболочек, предлагаемых как различными авторами, так и строительными нормами и правилами. В настоящей статье использованы классификации только по виду работы покрытия (жёсткие и висячие оболочки, мембранные покрытия, тросовые и вантовые структуры, пневматические и тентовые сооружения) и по используемому материалу (железобетонные, стальные, деревянные, композитные, армоцементные). Грамотный выбор материалов, правильное их использование в процессе строительства и дальнейшей эксплуатации - важное условие создания безопасных объектов, обладающих всеми необходимыми запланированными техническими и социальными характеристиками.

\section{$* * *$}

Впервые архитектурные стили и направления, рассмотренные в данной статье, хронология появления конструкционных материалов и история строительства оболочечных структур сведены в три таблицы ${ }^{5}$. Из них видно, что архитектурные стили (табл. 1 в первой части статьи [1]) появляются позже начала строительства оболочек и оболочечных структур (табл. 2). Строительство новых типов оболочечных структур (табл. 2) начинается почти одновременно или чуть позже появления новых строительных материалов (табл. 1).

Как указывается в первой части статьи «в начале XXI века архитекторы и инженеры всё больший интерес проявляют к проектированию оболочечных структур, что вызвано производственной необходимостью, появлением новых строительных материалов, разработкой математиками-геометрами новых геометрических форм, заинтересованностью молодых архитекторов в создании инновационных сооружений [16] и улучшенными эстетическими и эргономическими качествами общественных зданий».

Учитывая материалы, приведённые в настоящей статье, можно приступать к анализу и классификации архитектурных стилей, направлений и их подвидов, используемых в процессе проектирования оболочек, оболочечных и многогранных структур, как, например, это сделано геометрами для классификации аналитических поверхностей, приемлемых для формообразования оболочек

\section{Лuтература}

1. Кривошапко, С.Н. Оболочечные структуры: генезис, материалы и подвиды. Часть 1: Подвиды и направления / С.Н. Кривошапко, Л.А. Алборова, И.А. Мамиева // Архитектура и строительство. - 2021. - № 3. - С. 125-134. DOI: 10.22337/2077-9038-2021-3-125-134.

${ }^{4}$ https://www.building.co.uk/lucio-blandinis-glass-dome/3050203.article.

${ }^{5}$ Таблицу 1 см. № 3 журнала «Academia. Архитектура и строительство за этот год. 
2. Krasic, S. Geometrijske Površi u Arhitekturi / Sonja Krasic. - Gradevinsko-arhitektonski fakultet Univerzitet u Nišu, 2012. - 238 p.

3. Krivoshapko, S.N. Chronology of erection of the earliest reinforced concrete shells / S.N. Krivoshapko, A. Christian, Bock Hyeng, I.A. Mamieva // International Journal of Research and Reviews in Applied Sciences. - 2014. - Vol. 18. - Iss. 2. - P. 95-108. ISSN: 2076-734X, EISSN: 2076-7366.

4. Конструктивно- технологические возможности сборных сферических оболочек / В.И. Травуш, В.Д. Антошкин, Ерофеев В.Т. Ерофеев, С.С. Гудожников // Строительство и реконструкция. - 2013. - № 6 (50). -С. 36-48.

5. Кривошапко, С.Н. Из истории строительства деревянных оболочек и их возможности в настоящем и будущем / С.Н Кривошапко, К.П. Пятикрестовский // Строительная механика инженерных конструкций и сооружений. - 2014. - № 1. - C. 3-18.

6. Кривошапко, С.Н. Пневматические конструкции и сооружения / С.Н. Кривошапко // Строительная механика инженерных конструкций и сооружений. - 2015. - № 3. - С. 45-53.

7. Multi-Story Air-Supported and Fluid-Inflated Building Structures - Revised Edition: Concept, Design Principles, and Prototypes / Jens G. Pohl. . - California : California Polytechnic State University, San Luis Obispo, 2014. - 406 p.

8. Скопенко B.A. Тентовая архитектура: вчера, сегодня, завтра / В.А Скопенко. // Академический Вестник УралНИИпроект РАACH. - 2010. - № 1. - С. 30-31.

9. Кривошапко, С.Н. Вантовые конструкции общественных и промышленных зданий / С.Н. Кривошапко // Строительство и реконструкция. -2019. - № 1(81).- С. 23-47. DOI: 10.33979/2073-7416-2019-81-1-23-47.

10. Еремеев П.Г. Металлические конструкции покрытий уникальных большепролетных сооружений / П.Г. Еремеев // Промышленное и гражданское строительство. - 2007. № 3. - С. 19-21.

11. Еремеев П.Г., Киселёв Д.Б. Современные большепролетные комбинированные пространственные конструкции / П.Г. Еремеев, Д.Б. Киселёв // Пространственные конструкции зданий и сооружений (исследование, расчёт, проектирование, применение) : Сб. статей. - Вып. 9. - М.: Девятка Принт, 2004. - С. 159-166.

12. Knippers, Jan. Recent Developments in the Design of Glazed Grid Shells / Jan Knippers, Thorsten Helbig // International Journal of Space Structures. - June 2009. 24(2). - P. 111-126. D0I: 10.1260/026635109789043205.

13. Гринько, Е.А. Каплевидные оболочки / Е.А. Гринько // Строительная механика и расчет сооружений. - 2019. - № 6 (287). - C. 50-56.

14. Zhivotov, D. Construction of geodesic domes made of wood and composite materials during restoration and conservation of cultural heritage objects / D. Zhivotov, 0. Pastukh // E3S Web of Conferences 164, 02020 (2020) TPACEE-2019. 9 p. [https://doi.org/10.1051/e3sconf/202016402020].
15. Goel, S. Optimal segmentation of glass shell structures / S. Goel // Challenging Glass 5 // Conf. on Architectural and Structural Application of Glass Belis. Bos \& Louter (Eds.), Ghent University, June 2016. 8 р. ISBN 978-90-825-2680-6.

16. Мамиева И.А. 0 подготовке специалистов по архитектуре, геометрии и расчёту большепролетных пространственных структур и оболочек / И.А. Мамиева // Строительство и реконструкция. -2016. - № 5 (67). - С. 114-118.

\section{References}

1. Krivoshapko S.N., Alborova L.A., Mamieva I.A. Obolochechnye struktury: genezis, materialy i podvidy. Chast' 1: Podvidy i napravleniya [Shell structures: genesis, materials, and subtypes. Part 1. Subtypes and directions]. In: Academia. Arkhitektura i stroitel'stvo [Academia. Architecture and Construction], 2021, no. 3, pp. 125-134. D0I: 10.22337/20779038-2021-3-125-134. (In Russ., abstr. In Engl.)

2. Krasic Sonja. Geometrijske Površi u Arhitekturi. Gradevinsko-arhitektonski fakultet Univerzitet u Nišu, 2012. $238 \mathrm{p}$.

3. Krivoshapko S.N., Christian A. Bock Hyeng, Mamieva I.A. Chronology of erection of the earliest reinforced concrete shells. In: International Journal of Research and Reviews in Applied Sciences, 2014. Vol. 18. Iss. 2. Pp. 95-108. ISSN: 2076734X, EISSN: 2076-7366. (In Engl.)

4. Travush V.I., Antoshkin V.D., Erofeev V.T., Gudozhnikov S.S. Konstruktivno- tekhnologicheskie vozmozhnosti sbornykh sfericheskikh obolochek [Constructive and technological capabilities of prefabricated spherical shells]. In: Stroitel'stvo i rekonstruktsiya [Construction and reconstruction], 2013, no. 6 (50), pp. 36-48. (In Russ., abstr. In Engl.)

5. Krivoshapko S.N., Pyatikrestovskii K.P. Iz istorii stroitel'stva derevyannykh obolochek $\mathrm{i}$ ikh vozmozhnosti $v$ nastoyashchem $i$ budushchem [From the history of the construction of wooden shells and their possibilities in the present and future]. In: Stroitel'naya mekhanika inzhenernykh konstruktsii $i$ sooruzhenii [Building mechanics of engineering structures and structures], 2014, no. 1, pp. 3-18. (In Russ., abstr. In Engl.)

6. Krivoshapko S.N. Pnevmaticheskie konstruktsii i sooruzheniya [Pneumatic structures and structures]. In: Stroitel'naya mekhanika inzhenernykh konstruktsii i sooruzhenii [Building mechanics of engineering structures and structures], 2015, no. 3, pp. 45-53. (In Russ., abstr. In Engl.)

7. Jens G. Pohl. Multi-Story Air-Supported and FluidInflated Building Structures - Revised Edition: Concept, Design Principles, and Prototypes. - California Polytechnic State University, San Luis Obispo, California, 2014, 406 p. (In Engl.)

8. Skopenko V.A. Tentovaya arkhitektura: vchera, segodnya, zavtra [Tent architecture: yesterday, today, tomorrow]. In: Akademicheskii Vestnik UralNIIproekt RAASN [Academic Bulletin 
UralNIIproject RAACS], 2010, no. 1, pp. 30-31. (In Russ., abstr. In Engl.)

9. Krivoshapko S.N. Vantovye konstruktsii obshchestvennykh i promyshlennykh zdani [Cable-stayed structures for public and industrial buildings]. In: Stroitel'stvo i rekonstruktsiya [Construction and reconstruction], 2019, no. 1(81), pp. 23-47. DOI: 10.33979/2073-7416-2019-81-1-23-47. (In Russ., abstr. In Engl.)

10. Eremeev P.G. Metallicheskie konstruktsii pokrytii unikal'nykh bol'sheproletnykh sooruzhenii [Metal structures of coatings of uniquelarge-span structures]. In: Promyshlennoe i grazhdanskoe stroitel'stvo [Industrial and civil Engineering], 2007, no. 3, pp. 19-21. (In Russ., abstr. In Engl.)

11. Eremeev P.G., Kiselev D.B. Sovremennye bol'sheproletnye kombinirovannye prostranstvennye konstruktsii [Modern large-span combined spatial structures]. In: Prostranstvennye konstruktsii zdanii i sooruzhenii (issledovanie, raschet, proektirovanie, primenenie): Sb. Statei [Modern large-span combined spatial structures. Coll.of art.], Iss. 9. Moscow, Devyatka Print Publ., 2004, pp. 159-166. (In Russ.)

12. Knippers Jan, Helbig Thorsten. Recent Developments in the Design of Glazed Grid Shells. In: International Journal of Space Structures, June 2009, no. 24(2), Pp. 111-126. D0I: 10.1260/026635109789043205. (In Engl.)
13. Grin'ko E.A. Kaplevidnye obolochki [Drop-shaped shells]. In: Stroitel'naya mekhanika $i$ raschet sooruzhenii [Building mechanics and calculation of structures], 2019, no. 6 (287), pp. 50-56. (In Russ., abstr. In Engl.)

14. Dmitry Zhivotov, Olga Pastukh. Construction of geodesic domes made of wood and composite materials during restoration and conservation of cultural heritage objects. In: Topical Problems of Green Architecture, Civil and Environmental Engineering 2019 (TPACEE 2019). Moscow, Russia, November 19-22, 2019. Moscow, 2020, 9 p. [https://doi.org/10.1051/ e3sconf/202016402020].

15. Goel S. Optimal segmentation of glass shell structures. In: Challenging Glass 5. Conf. on Architectural and Structural Application of Glass Belis. Bos \& Louter (Eds.), Ghent University, June 2016. Belgium, Ghent University Publ., 2016, Vol. 5, 8 p. ISBN 978-90-825-2680-6.

16. Mamieva I.A. 0 podgotovke spetsialistov po arkhitekture, geometrii i raschetu bol'sheproletnykh prostranstvennykh struktur i obolochek [0n the training of specialists in architecture, geometry and calculation of large-span spatial structures and shells]. In: Stroitel'stvo $i$ rekonstruktsiya [Construction and reconstruction], 2016, no. 5 (67), pp. 114-118. (In Russ., abstr. In Engl.) 